\title{
GEOQUIMICA DOS GRANULITOS BÁSICOS E ANFIBOLITOS DE PARTE DAS REGIÓES SUDESTE E SUL DO BRASIL
}

\author{
M.A.F.Oliveira ${ }^{1}$, A.Zanardo ${ }^{1}$, F.A.Negri ${ }^{2}$, V.Maniesi ${ }^{3}$, S.C.Souza ${ }^{3}$
}

A presente pesquisa diz respeito às ocorrências de rochas básicas granulíticas situadas nas regiões de São José do Rio Pardo - Guaxupé e São Francisco Xavier - Monteiro Lobato, ambas na divisa entre São Paulo e Minas Gerais, bem como ocorrências de anfibolitos relacionados ao Complexo Itapira nas regiões de Águas de Lindóia e Cabreúva, ao Grupo São Roque na região de Sorocaba e aos Grupos Açungui e Setuva nas regiões de Campo Largo, Rio Branco do Sul e Adrianópolis, as três últimas no estado do Paraná.

Os dados químicos referem-se a determinações de elementos maiores, elementos traços, elementos terras raras e alguns elementos incompatíveis.

Na região de São Francisco Xavier - Monteiro Lobato (SP), onde se destaca a presença de corpo de rocha charnokítica inserida em contexto gnaisse-migmatítico-granulítico, foram estudadas numerosas ocorrências de granulitos básicos e anfibolitos (Negri, 1995). Os granulitos básicos ocorrem como intercalações, cuja espessura varia de métrica a decamétrica, dispostas concordantemente com a foliação dos paragnaisses encaixantes, sendo muito comum sua associação com enderbitos. As exposições de anfibolitos são menos freqüentes que as de granulitos básicos, constituindo também corpos concordantes. 0 exame dos dados químicos indica tendências equivalentes às de uma série tolética subalcalina, relacionada possivelmente a basaltos de fundo oceânico. O padrão dos ETR mostra-se pouco enriquecido em relação ao NMORB e é característico das rochas máficas. Dentro do contexto geológico global esta área pode ser interpretada como resultante de um evento de colisão continental, permitindo supor a existência de um magmatismo bimodal.

Os dados geoquímicos, referentes à faixa que se estende entre São José do Rio Pardo (SP) e Guaxupé (MG) (Oliveira et al., 1993), incluem novas análises de ETR e elementos incompativeis. Observa-se enriquecimento em ETRL, com padrões compatíveis com os de toleitos arqueanos do tipo TH2 e toleitos modernos de tendência cálcio alcalina (Condie, 1981), sendo a segunda hipótese a mais provável. 0 enriquecimento em ETRP pode ser explicado pela presença de granada ou anfibólio na fase residual (Figueiredo \& Hartmann, 1989). Os conteúdos de NB, Zr e Y sugerem origem em ambiente de arco vulcânico.

Os anfibolitos na região de Águas de Lindóia (SP) ocorrem como intercalações tabulares de espessuras centimétricas a métricas, raramente ultrapassando $100 \mathrm{~m}$. São compostos basicamente por hornblenda e plagioclásio (andesina-labradorita), contendo por vezes pequenas quantidades de clinopiroxênio.

Composição semelhante é observada para os anfibolitos que ocorrem na região de Cabreúva (SP) que constituem corpos concordantes encaixados em paragnaisses e

\footnotetext{
${ }^{1}$ Instituto de Geociências e Ciências Exatas, Universidade Estadual Paulista.

${ }^{2}$ IG-SMA, São Paulo.

${ }^{3}$ Pós-graduando do Instituto de Geociências e Ciências Exatas, Universidade Estadual Paulista .
} 
migmatitos.

Os dados geoquímicos para ambas regiões permitem interpretar essas litologias como equivalentes a toleitos subalcalinos, com leve enriquecimento nos ETRL e pequeno empobrecimento nos ETRP, com algumas amostras registrando anomalia negativa de Ce.

Os resultados referentes ao Grupo São Roque permitem concluir que os anfibolitos de fácies xistos verdes média a alta exibem tendência equivalente a toleítos subalcalinos de baixo potássio, gerados provavelmente em ambiente tectônico de margem de placa convergente. Os ETR evidenciam tendência bastante horizontalizada, com leve enriquecimento em ETRL.

Na porção nordeste do estado do Paraná, ocorrem corpos de anfibolitos de natureza ortoderivada, inseridos em rochas metassedimentares pertencentes aos Grupos Açungui (regiões de Adrianópolis e Rio Branco do Sul) e Setuva (região de Campo Largo).

Nesses corpos, segundo o diagrama R1 vs. R2 são encontrados predominantemente litotipos de composição de andesi basaltos e basaltos subalcalinos. Possuem afinidade toleítica, subalcalina, caracterizada pela baixa razão álcalis/sílica e pelo enriquecimento em $\mathrm{F}(\mathrm{FeOt})$ em relação a $\mathrm{A}\left(\mathrm{Na}_{2} \mathrm{O}+\mathrm{K}_{2} \mathrm{O}\right)$ e $\mathrm{M}(\mathrm{MgO})$ no diagrama AFM. Nesses diagramas as rochas dos corpos de Adrianópolis destacam suas afinidades toleíticas quando comparadas com as rochas de Campo Largo e Rio Branco do Sul, além de apresentarem-se mais ricas em Fe, P, Sr e Zr.

Nos diversos diagramas de variação envolvendo os elementos maiores e traços, bem como os padrões de abundância dos elementos terras raras, apresentam evidências de que esses corpos tiveram líquidos magmáticos iniciais do mais evoluído ao mais primitivo na seguinte ordem: anfibolitos de Adrianópolis, Campo Largo e Rio Branco do Sul, além de possuírem respectivamente linhas de tendências evolutivas diferentes entre si. Essas caracteristicas sugerem a atuação de diferentes graus de fusão parcial de fontes mantélicas composicionalmente distintas.

\section{Referências Bibliográficas}

CONDIE, K.C. (1981) Archean greenstones belts. Amsterdam, Elsevier. 434p.

FIGUEIREDO, M.C.H.; HARTMANN, L.A. (1989) Geoquímica dos elementos terras raras em granulitos e charnokitos do Brasil. In: FORMOSO, M.L.L.; NARDY, L.U.S.; HARTMANN, L.A. (Eds.) Geoquímica dos elementos terras raras do Brasil. Rio de Janeiro, CPRM/DNPM/SBGq, p.99-105.

NEGRI, F.A. (1995) Geologia das rochas charnokíticas e associadas na região de São Francisco Xavier, SP. Rio Claro. (Dissertação-Mestrado) - IGCE-UNESP.

OLIVEIRA, M.A.F.; ALVES, F.R.; KIHARA, Y. (1993) Mafic granulites and amphibolites of the São José do Rio Pardo - Caconde high grade terrain. Geochimica Brasiliensis, v.7, n.2, p.89-100. 